\title{
In Vitro Comparative Cytotoxicity Study of Aminated Polystyrene, Zinc Oxide and Silver Nanoparticles on a Cervical Cancer Cell Line
}

\author{
Akash Sharma \\ Technological University Dublin \\ Brian Gorey \\ Technological University Dublin \\ Alan Casey \\ Technological University Dublin, alan.casey@tudublin.ie
}

Follow this and additional works at: https://arrow.tudublin.ie/nanolart

Part of the Nanotechnology Commons

\section{Recommended Citation}

Sharma, A., Gorey, B. \& Casey, A. (2017). In Vitro Comparative Cytotoxicity Study of Aminated Polystyrene, Zinc Oxide and Silver Nanoparticles on a Cervical Cancer Cell Line. Drug and Chemical Toxicology, vol 23, pp. 1-15. doi.org/10.1080/01480545.2018.1424181.

This Article is brought to you for free and open access by the NanoLab at ARROW@TU Dublin. It has been accepted for inclusion in Articles by an authorized administrator of ARROW@TU Dublin. For more information, please contact arrow.admin@tudublin.ie, aisling.coyne@tudublin.ie,gerard.connolly@tudublin.ie.

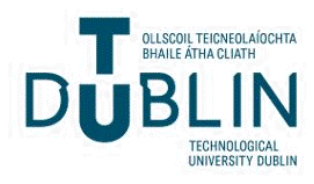




\section{In vitro comparative cytotoxicity study of aminated polystyrene, zinc oxide and silver nanoparticles on a cervical cancer cell line}

\section{Akash Sharma, Brian Gorey \& Alan Casey}

To cite this article: Akash Sharma, Brian Gorey \& Alan Casey (2018): In vitro comparative cytotoxicity study of aminated polystyrene, zinc oxide and silver nanoparticles on a cervical cancer cell line, Drug and Chemical Toxicology, DOI: 10.1080/01480545.2018.1424181

To link to this article: https://doi.org/10.1080/01480545.2018.1424181

曲 Published online: 23 Jan 2018.

Submit your article to this journal $₫$

Q View related articles $\sqsubset$

View Crossmark data $\complement$ 


\title{
In vitro comparative cytotoxicity study of aminated polystyrene, zinc oxide and silver nanoparticles on a cervical cancer cell line
}

\author{
Akash Sharma $^{\mathrm{a}, \mathrm{b}}$, Brian Gorey ${ }^{\mathrm{a}}$ and Alan Casey ${ }^{\mathrm{a}, \mathrm{b}}$

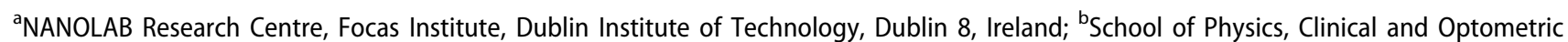 \\ Sciences, Dublin Institute of Technology, Dublin, Ireland
}

\begin{abstract}
Nanoparticles use in nano-biotechnology applications have increased significantly with Aminated polystyrene amine (AmPs NP), Zinc oxide (ZnO NP), and Silver (Ag NP) nanoparticles utilized in wide variety of consumer products. This has presented a number of concerns due to their increased exposure risks and associated toxicity on living systems. Changes in the structural and physicochemical properties of nanoparticles can lead to changes in biological activities. This study investigates, compares, and contrasts the potential toxicity of AmPs, ZnO and Ag NPs on an in vitro model (HeLa cells) and assesses the associated mechanism for their corresponding cytotoxicity relative to the surface material. It was noted that NPs exposure attributed to the reduction in cell viability and high-level induction of oxidative stress. All three test particles were noted to induce ROS to varying degrees which is irrespective of the attached surface group. Cell cycle analysis indicated a G2/M phase cell arrest, with the corresponding reduction in G0/G1 and S phase cells resulting in caspase-mediated apoptotic cell death. These findings suggest that all three NPs resulted in the decrease in cell viability, increase intracellular ROS production, induce cell cycle arrest at the G2/M phase and finally result in cell death by caspase-mediated apoptosis, which is irrespective of their differences in physiochemical properties and attached surface groups.
\end{abstract}

ARTICLE HISTORY

Received 19 October 2017

Revised 23 November 2017

Accepted 27 December 2017

\section{KEYWORDS}

Nanotoxicity; aminated nanoparticles; zinc oxide nanoparticles; silver nanoparticles; in vitro toxicity; reactive oxygen species; apoptosis

\section{Introduction}

Nanoparticles (NPs) are used in a variety of applications resulting in multiple different routes of exposure by the consumer, but comprehensible results on their toxicity are not fully understood (Auffan et al. 2009, Wilhelmi et al. 2012). Due to NPs increase usage in a wide range of practical applications of nano-biotechnology (Vamanu et al. 2008), a better understanding of the cytotoxic effect of NPs is essential and a full assessment of the potential risk and adverse effects of NPs on living systems must be identified (Haynes 2010). The increased usage of engineered NPs has led to elevated concerns regarding their safety due to the variability of their chemical composition (De Matteis 2017). As nanoparticles can be produced by different chemical synthetic methods, engineered NPs are classified into three main categories: inorganic NPs, which include quantum dots (QDs), metal oxides (Zinc oxide NPs, Silicon dioxide, Titanium dioxide) to metallic NPs (Silver NPs, Gold NPs), organic NPs such as chitosan, synthetized with organic compounds and carbon-based NPs such as carbon nanotubes (De Matteis 2017). Due to the vast differences in their physico-chemical properties, primarily resultant from their differing synthesis methods, they are known to induce adverse effects in biological systems. NPs can interfere with cellular systems by the NPs interaction's with proteins, DNA, lipids, membrane, organelles, and biological fluids (Roiter et al. 2008, Shang et al. 2014, Khan et al. 2015). Due to their reduced size $(1-100 \mathrm{~nm})$ and large surface area to volume ratio, they can easily cross cell membranes (Khan et al. 2015) and further enter the bloodstream reaching different organs (Vishwakarma et al. 2010). Their interactions with the culture medium or biological fluids have also been reported to be an important consideration for their toxicological evaluation due to the increased probability of aggregation upon dispersion in these environments, which is known to influence their cellular uptake with a subsequent impact on their toxicity (De Matteis 2017). As aggregation is strongly dependent on NPs surface charge, material and solubility, their stability in culture media can be difficult to control and adverse effects originating from NPs associated toxicity and not indirect effects (Casey et al. 2008) caused by the local environment are still unclear and as such warrant further assessment (De Matteis 2017).

NPs commonly used in nano-biotechnology applications and market available consumer products are of particular interest to this study. All the NPs under test, Silver (Ag), Zinc oxide ( $\mathrm{ZnO}$ ), and Aminated polystyrene (AmPs) nanoparticles were specifically chosen to be different in their physiochemical properties facilitating their mechanism of cytotoxic action to be studied as a function of material and surface group. HeLa cells, an immortal cervical cancer cell line was chosen to understand the mechanism of action for NPs under test as 
a standard model due to their global availability within the research community.

Ag NPs are found in range of medical applications: wound dressings, contraceptive devices, surgical instruments (Dingchao et al. 2004, Chen et al. 2006, Lansdown 2006, Muangman et al. 2006, Cohen et al. 2007, Sotiriou and Pratsinis 2010) and consumer products, which includes antibacterial room spays, laundry detergents, water purifiers, and wall paint (Dingchao et al. 2004, Sotiriou and Pratsinis 2010). Ag NPs have been reported to decrease colon cancer cells viability in vitro, subsequently, induce apoptosis and cell cycle arrest (Murphy et al. 2016). Due to Ag NPs widespread usage and reported cytotoxic properties of AgNP, studies monitoring their interactions within the biological environment of the cells are necessary due to the changes Ag NPs can undergo in the environmental and indeed in biological media. Their exposures at sub-lethal concentrations have also shown to induce immune reactions, resulting in the induction of interleukin (IL)-8 and the generation of reactive oxygen species (Murphy et al. 2016). Upon inhalation, they have also shown to infiltrate the alveolar cell wall causing dysfunction of the cytokine network and further infiltrating the blood stream (Murphy et al. 2016). Displacement of the surfacecoating agents upon their dispersion in biological media, such as citric acid, amino acids, cetyl trimethylammonium bromide, sodium dodecyl sulfate, which are noncovalently attached to Ag NPs by other biological macromolecules, inorganic and organic ions can make Ag NPs unstable and undergo aggregation (McShan et al. 2014). Silver atoms on the surface of Ag NPs were also found to oxidized to silver oxide upon their interaction with molecular oxygen and interactions of silver oxide with the media can also attribute to the release of silver ions in the biological media, as well as inside the cell (McShan et al. 2014). The strong oxidative activity of Ag NPs surfaces and the release of $\mathrm{Ag}$ ions to the biological environment also attributes to their antimicrobial activity (Zhang et al. 2014). Previously conducted toxicological evaluations of Ag NPs have also indicated that it kill cells through a Trojan-horse type mechanism, suggesting that the release of $\mathrm{Ag}^{+}$ions upon $\mathrm{Ag}$ NPs intracellular accumulation (Kovács et al. 2016). The release of $\mathrm{Ag}^{+}$ions induces reactive oxygen species (ROS) generation thereby unbalancing the redox homeostasis of the cell (Kovács et al. 2016). This furthermore produces adverse effects on the overall cell functionality inducing cytotoxic and immunological responses and ultimately cell death (Zhang et al. 2014). The use of Ag NPs in a vast array of applications has increased their interaction with tissue, cells and biological molecules of human body making their toxicological evaluation necessary. This study will also help to understand the underlying mechanisms involved in Ag NPs associated cytotoxicity and evaluate their impact on biological systems involved.

Similarly, ZnO NPs can be found in many skin care products, such as sunscreen lotions, creams, and cosmetics and other industrial and medical applications (Yang and $\mathrm{Ma}$ 2014). Due to ZnO NPs high UV light absorption and reflective properties, $\mathrm{ZnO}$ NPs provide protection from ultraviolet radiation $A$ and $B$ and hence justifies their use in sunscreens and paints (Senapati et al. 2017). In its original form, $\mathrm{ZnO}$ is a low toxic material commonly present in food and added as a nutritional supplement, but at the nano-scale, its increased chemical reactivity, oxidation resistance and UV filtering efficiency are the reason it has found increased commercial use (Shalini et al. 2017). Despite their widespread usage in consumer products, the mechanism for their cytotoxicity is not well known and the in vitro cytotoxic effects of ZnO NPs, therefore, must be fully understood. The physiochemical characteristics of ZnO NPs, surface reactivity, particle number, dissolution, chemical composition etc. play an important part in its toxicological response, specifically ZnO NPs toxicity has been attributed to the release of free ionic zinc, that induces free ROS which, results in subsequent cellular damage and finally cell death (Shalini et al. 2017). ZnO NPs mediated cytotoxicity has been noted to be dependent on their surface properties (Saptarshi et al. 2013) and their cellular uptake has been shown to occur via endocytosis (Kao et al. 2012, Jeong et al. 2013, Yan et al. 2014). ZnO NPs are initially recognized by the phagocytes, which further ingest them into the phagosomes, which are then acidified by phagosomes/lysosomes fusion (Cho et al. 2011). The resultant dissolution of the $\mathrm{ZnO}$ NPs to its ions in the acidic micro-environment inside phagosomes/lysosomes causes lysosomal destabilization and subsequent cell death, which is regarded as the most accepted pathway for ZnO NPs induced toxicity (Pokhrel et al. 2009, Cho et al. 2011, Zhang et al. 2017). ZnO NPs interaction with immune system due to their accumulation in spleen and lymph nodes has been shown in a mice in vivo model (Senapati et al. 2017), where ZnO NPs have also been found to induce the release of inflammatory cytokines and causing an imbalance of Th-1/Th-2 cells (Senapati et al. 2017). Others suggest that in in vitro conditions, the ZnO NPs interact with the phosphates present in cell culture medium and the added proteins (10\% FBS) of cell culture (Hsiao and Huang 2013, Everett et al. 2014). Also, the interactions with the added FBS result in a shielding of the NPs surface by the attached proteins with the effect of altering their structure presented to the cell (Saptarshi et al. 2013). NPs induced changes in the absorbed protein structure can alter their bioactivity (Saptarshi et al. 2015). However, information related to effects on nano-toxicological properties of ZnO NPs from protein adsorption on their surface are still under investigation and will be further evaluated in this study.

AmPs NPs toxicity has also been studied with various human cell lines by using conventional cytotoxicity evaluation and microscopic studies (Wang et al. 2013, Anguissola et al. 2014). In most studies, endocytosis has been described as the primary mechanism for AmPs NPs uptake into the cells. Early endosomes carry the NPs to the lysosomes across the cell membrane (Treuel et al. 2013) and they are further engulfed by the lysosomes and carried to the endoplasmic reticulum (Shapero et al. 2011, Mu et al. 2012, Efeoglu et al. 2016). It is widely accepted that AmPs NPs induce toxicity which is initiated by the formation of ROS following the endocytosis of NPs (Lunov et al. 2011, Efeoglu et al. 2016). Furthermore, due to induced oxidative stress, inflammatory factors are release and apoptosis is triggered (Lunov et al. 2011, Efeoglu et al. 2016). But it has not yet been confirmed that AmPs NPs induced cytotoxicity can be caspase-mediated, 
triggering the apoptotic pathway due to their cationic properties. It has been postulated that $\mathrm{B}$ cell lymphoma $2(\mathrm{BCl}-2)$ proteins located on the mitochondrial membrane can cause the formation of holes, which further release apoptogenic factors and trigger caspase activity (Xia et al. 2008, Bexiga et al. 2011, Ruenraroengsak et al. 2012, Anguissola et al. 2014).

Although the underlying mechanism of NPs induced cytotoxicity is not fully understood, oxidative stress, lipid peroxidation, and reduced glutathione (GSH) levels have been reported to play important roles in inducing DNA damage, apoptosis, cell membrane disruption, and ultimately cell death (Hussain et al. 2005, Piao et al. 2011, Singh and Ramarao 2012, Govender et al. 2013, Khan et al. 2015). In the study presented here, the in vitro cytotoxic response of AmPs, $\mathrm{ZnO}$, and Ag NPs in HeLa cells was studied, the physiochemical characteristics of NPs have previously been shown to play an important role in the toxicological investigation (Mukherjee et al. 2012) and will be studied in conjunction with the in vitro screening here. Characterization of nanoparticles was performed using Dynamic light scattering (DLS), Scanning electron microscopy (SEM) and Zeta potential analysis. NPs size distribution and agglomerative state upon dispersion in cell culture medium were also investigated with the aid of DLS. Toxicological evaluations were conducted by employing variety of viability assays, including Alamar Blue (AB), Neutral Red (NR), 3-(4,5-Dimethyl- thiazol-2-yl)-2,5-diphenyltetrazolium bromide (MTT), and a 2', $7^{\prime}$-dichlorofluorescein diacetate (DCFH-DA) plate assay to detect intracellular oxidative stress induced by exposure. The interpretation of dose response to assess the toxicity from these assays helps to understand the cellular response upon NPs exposure. Further studies were performed to evaluate the effects on the release of intracellular reactive oxygen species via confocal microscopic analysis. Cell cycle analysis and live, apoptotic and necrotic population's post-NP exposure were performed using flow cytometry, to verify if NPs did induce apoptosis and could alter the cell cycle. The data presented in this study demonstrate that all the tested NPs induced cytotoxicity in a time and dose-dependent manner furthermore generating intracellular ROS production, with a subsequent cell cycle arrest at the G2/M phase and finally activated a caspasemediated apoptosis, which was irrespective of their differences in physiochemical properties and attached surface groups.

\section{Materials and methods}

\subsection{Test materials and reagents}

Ag NPs Nano powder water dispersion $(\mathrm{Ag}, 15 \mathrm{~nm}$ ) were purchased from US Research Nanomaterial, Inc. Latex beads, AmPs NPs ( $50 \mathrm{~nm}$ mean particle size), ZnO NPs Nano powder ( $\mathrm{ZnO},<100 \mathrm{~nm}$ particle size), 3-(4,5-Dimethylthiazol-2-yl)-2,5diphenyltetrazolium bromide (MTT), Neutral Red (NR), Propidium lodide (PI), Doxorubicin hydrochloride ${ }^{\circledR}(\mathrm{DOX})$, and $2^{\prime}, 7^{\prime}$-dichlorofluorescin diacetate (DCF) as well as all cell culture media, supplements, the trypsinisation solution were all purchased from Sigma Aldrich Ltd. (Ireland). AB, Cell event Caspase 3/7 Green Flow Cytometry Kit and KaryoMax
Colcemid Solution in HBBS were all purchased from Biosciences (Dublin, Ireland).

\subsection{Cell culture}

HeLa, an immortal cell line derived from a cervical cancer were purchased from the ATTC (Manassas, VA). HeLa cells were cultured in RPMI-1640 medium supplemented with $10 \%$ FBS (fetal bovine serum), $45 \mathrm{IU} / \mathrm{ml}$ penicillin, $45 \mathrm{IU} / \mathrm{ml}$ streptomycin, and L-glutamine (1\%) (HeLa media) at $37^{\circ} \mathrm{C}$ in a humidified incubator at $5 \% \mathrm{CO}_{2}$.

\subsection{Characterization of nanoparticles}

All test samples, AmPs, $\mathrm{ZnO}$ and Ag NPs were fully characterized by Dynamic light scattering (DLS), Zeta potential and SEM analysis before any biological testing. All measurements where possible were performed on all NPs in suspension form in both ultra-pure water $\left(\mathrm{dH}_{2} \mathrm{O}\right)$ and HeLa media, sample dispersion was ensured by using a bath-sonicator (Degussa-Ney ULTRAsonik 57X, 50/60 Hz, Yucaipa, CA) for $15 \mathrm{~min}$ at room temperature before any analysis. DLS and Zeta potential measurements were performed with Malvern Zeta Silver nano ZS (Malvern Instruments, Worcestershire, UK) and data were evaluated using DTS Nano software (version 7.11). Size measurements were performed using disposable cuvettes. For analysis, refractive indices of NPs (AmPs: 1.590, $\mathrm{ZnO}: 2.003$, and Ag: 0.999), $\mathrm{dH}_{2} \mathrm{O}$ (1.330) and HeLa media (1.338) (Mukherjee et al. 2012) were incorporated in the DLS size measurement settings via the DTS Nano software (version 7.11). Viscosity measurement was performed and recorded using Viscometer SV-10 (A\&D Instruments Ltd., UK) at $25^{\circ} \mathrm{C}$ for $\mathrm{dH}_{2} \mathrm{O}(0.8872 \mathrm{cP})$ and HeLa media $(0.8900 \mathrm{cP})$ which were also incorporated in the DLS size measurement settings via the DTS nano software (version 7.11).

Zeta potential measurements for AmPs, ZnO, and Ag NPs were performed using DTS1070 clear disposable zeta cells with an applied voltage of $5 \mathrm{~V}$ and corresponding zeta potential was calculated using Smoluchowski equation in the DTS nano software.

SEM micrographs were obtained for all NPs using a Hitachi SU 6600 Field emission SEM instrument (Hitachi UK) at an accelerating Voltage of 25 or $20 \mathrm{kV}$, probe current of $18-20 \mu \mathrm{A}$ and a working distance of $6 \mathrm{~mm}$ in secondary electron mode (AmPs and $\mathrm{ZnO} \mathrm{NPs}$ ) and transmitted electron mode (Ag NPs). Prior to SEM analysis samples were prepared by dispersing AmPs, ZnO, and Ag NPs in ethanol $(10 \mathrm{mg} / \mathrm{l})$ using Ultrasonic Processor tip (Branson Ultrasonics, Ultrasonic processor V(X-750 W) for $45 \mathrm{~s}$ at $40 \%$ amplitude. About $3 \mu \mathrm{l}$ of each test solution was then drop cast onto a Formvar carbon mesh grid (Aquilant Scientific, 21 Fonthill Business Park D22) and allowed to air dry before imaging.

\subsection{Cytotoxicity evaluation}

Cytotoxicity assessment for $\mathrm{AmPs}, \mathrm{ZnO}$, and $\mathrm{Ag} \mathrm{NPs}$ were conducted using $A B, N R$, and $M T T$ assays, where a concentration range of interest was identified by initially performing 
range finding tests. Following initial range finding tests, the definitive test used a concentration range of nine concentrations in which effects were likely to occur as indicated by the range finding tests, thereby permitting the calculation of the respective half maximal inhibitory concentration $\left(\mathrm{IC}_{50}\right)$, no observed effect concentration (NOEC) and lowest observed effect concentration (LOEC). Unexposed control cells were also employed in all assays to compare the corresponding results eliminating any dependence of cell line exposures on volumes, well type, seeding efficiency and numbers, exposure times, etc. In all viability experiments, a 10\% dimethyl sulfoxide (DMSO) was also used as a positive kill control to validate assay function in all AmPs, $\mathrm{ZnO}$ and Ag NPs exposures. For testing, stock concentrations of all NPs were prepared using fully supplemented HeLa media, which were diluted further with fully supplemented HeLa media by serial dilution for definitive concentration range, followed by bath sonication (Degussa-Ney ULTRAsonik 57X, Yucaipa, CA) for $10 \mathrm{~min}$ at room temperature before exposure.

\subsubsection{Alamar blue and neutral red assay}

For the $A B$ and NR assays, cells were seeded in 96-well microtiter plates (Nunc, Denmark) at a density of $1 \times 10^{5}$ cells $/ \mathrm{ml}$ for $24 \mathrm{~h}$ exposure, $7 \times 10^{4}$ cells $/ \mathrm{ml}$ for $48 \mathrm{~h}$ exposure, and $3 \times 10^{4}$ cells $/ \mathrm{ml}$ for $72 \mathrm{~h}$ exposures respectively, in $100 \mu \mathrm{l}$ of medium containing 10\% FBS. Three independent experiments were conducted and eight replicate wells were employed per concentration per plate. Following $24 \mathrm{~h}$ of cell attachment, plates were washed with $100 \mu \mathrm{l} /$ well phosphate buffered saline (PBS) and further treated with $100 \mu \mathrm{l} /$ well of respective 0.039-10 $\mu \mathrm{M}$ AmPs, $4.7-1.22 \times 10^{3} \mu \mathrm{M} \quad \mathrm{ZnO}$, and $1.76-4.63 \times 10^{2} \mathrm{Ag}$ NPs concentration range prepared in HeLa media for 24,48 , and $72 \mathrm{~h}$, respectively. The $A B$ assay was performed first followed by the NR assay and the assays were carried out in accordance with manufacturer's instruction. Briefly, control media or test exposures were removed; the cells were rinsed with PBS and $100 \mu \mathrm{l}$ of AB/NR medium ( $5 \%$ $[v / v]$ solution of $A B$ and $1.25 \%[v / v]$ of $N R$ dye) prepared in fresh media (without FBS or supplements) were added to each well. After $3 \mathrm{~h}$ incubation $A B$ fluorescence was measured at the respective excitation and emission wavelength of 531 and $595 \mathrm{~nm}$ in a SpectraMax M3 Multi-Mode Microplate Reader (Molecular Devices, Sunnyvale, CA). Wells having only $A B$ and media were used as blanks. After measurement, the wells were then washed with PBS and $100 \mu \mathrm{l}$ of NR fixative (50\% ethanol, $49 \% \mathrm{dH}_{2} \mathrm{O}$, and $1 \%$ glacial acetic acid) was added to each well and the plates were shaken at $240 \mathrm{rpm}$ for $10 \mathrm{~min}$. The NR fluorescence was then measured at the excitation and emission wavelength of 531 and $642 \mathrm{~nm}$, respectively in the same instrument. For these assays, mean fluorescence/absorbance units for the six replicate cultures were calculated for each exposure treatment.

\subsubsection{MTT assay}

Cells were seeded in at the same densities as described earlier in the $A B$ and NR assay method and again three replicates for each AmPs, ZnO, and Ag NPs were employed for the MTT assay. After 24, 48, and $72 \mathrm{~h}$ of AmPs, $\mathrm{ZnO}$, and $\mathrm{Ag}$ NPs exposure, the medium for the controls or test exposures were removed, the cells were washed with PBS.A stock solution of MTT was prepared $(5 \mathrm{mg} / 5 \mathrm{ml}$ of $M T T$ in PBS) and $100 \mu \mathrm{l}$ of freshly prepared MTT in media $(1 \mathrm{ml} / 10 \mathrm{ml}$ of MTT stock in media (without FBS or supplements) were added to each well. After $3 \mathrm{~h}$ incubation, the medium was discarded and the cells were rinsed with PBS and $100 \mu$ of MTT fixative solution (DMSO) was added to each well and the plates were shaken at $240 \mathrm{rpm}$ for $10 \mathrm{~min}$. The absorbance was then measured at $595 \mathrm{~nm}$ in a SpectraMax M3 Multi-Mode Microplate Reader (Molecular Devices, Sunnyvale, CA).

\subsection{Reactive oxygen species study}

For reactive oxygen species (ROS) assay, cells were seeded at $1 \times 10^{5}$ cells $/ \mathrm{ml}$ in $100 \mu$ of medium containing $10 \%$ FBS into black bottomed 96 well plates (Nunc, Denmark) and incubated for $24 \mathrm{~h}$ at $37^{\circ} \mathrm{C}$. Three independent experiments were conducted and eight replicate wells were employed per concentration per plate. Following $24 \mathrm{~h}$ of cell attachment, cells were washed with $100 \mu \mathrm{l} /$ well with PBS and further treated with $100 \mu \mathrm{l} /$ well of $10 \mu \mathrm{M}$ DCFH-DA prepared in PBS and incubated for $1 \mathrm{~h}$. After $1 \mathrm{~h}$ exposure time, plates were washed with $100 \mu \mathrm{l} /$ well PBS and further treated with $100 \mu \mathrm{l} /$ well of $0.039-10 \mu \mathrm{M} \quad$ AmPs, $4.7-1.22 \times 10^{3} \mu \mathrm{M} \quad \mathrm{ZnO}$, and $1.76-4.63 \times 10^{2} \mathrm{Ag}$ NPs concentration range and controls consisting of eight replicate wells per plate for each experiment prepared in HeLa media for $24 \mathrm{~h}$. The negative control was made of HeLa media and the positive control was made of $1 \mu \mathrm{M}$ Hydrogen Peroxide $\left(\mathrm{H}_{2} \mathrm{O}_{2}\right)$ prepared in HeLa media. Cells were further rinsed with $100 \mu \mathrm{l} /$ well with PBS and incubated with $100 \mu \mathrm{l} /$ well PBS for 30, 60, 120, 180, 240, 300, $360 \mathrm{~min}$. The rate of intracellular oxidative stress was then monitored by DCFH-DA dye excitation at $504 \mathrm{~nm}$ and emission recorded at $529 \mathrm{~nm}$ in a SpectraMax M3 Multi-Mode Microplate Reader (Molecular Devices, Sunnyvale, CA) at various time intervals of 30-360 min (the exposure plates were re-incubated for the remaining time after each measurement had been recorded).

\subsection{Confocal microscopy}

HeLa cells were seeded at a density of $1 \times 10^{5}$ cells $/ \mathrm{ml}$ in $500 \mu \mathrm{l}$ of HeLa medium containing 10\% FBS in Matek $35 \mathrm{~mm}$ glass-bottomed culture vessels (MatTek Corporation, Ashland, $\mathrm{MA}$ ) for $3 \mathrm{~h}$ incubation at $37^{\circ} \mathrm{C}$ in $5 \% \mathrm{CO}_{2}$. Following $3 \mathrm{~h}$ incubation, $1 \mathrm{ml}$ of HeLa media was added to the cell suspension and they were further incubated for $24 \mathrm{~h}$ at $37^{\circ} \mathrm{C}$ in $5 \% \mathrm{CO}_{2}$ for cell attachment. After the $24 \mathrm{~h}$ incubation period, cells were washed with PBS and further treated with $5 \mu \mathrm{M} \mathrm{AmPs,}$ $614 \mu \mathrm{M} \mathrm{ZnO}$, and $463.56 \mu \mathrm{M}$ Ag NP concentrations respectively and controls and incubated for another $6 \mathrm{~h}$ at $37^{\circ} \mathrm{C}$ in $5 \% \mathrm{CO}_{2}$. The negative control was made of HeLa media and the positive control was made of $1.5 \mathrm{ml}$ of $1 \mu \mathrm{M}$ Hydrogen Peroxide $\left(\mathrm{H}_{2} \mathrm{O}_{2}\right)$ prepared in HeLa media as positive ROS inducer control. Following $6 \mathrm{~h}$ incubation, cells were washed twice with $2 \mathrm{ml}$ PBS and stained with $500 \mu \mathrm{l}$ of $10 \mu \mathrm{M}$ 
DCFH-DA prepared in PBS. Cells were incubated for $20 \mathrm{~min}$ and washed with $2 \mathrm{ml}$ PBS before imaging. Images were taken on a Zeiss 510 (Oberkochen, Germany) LSM confocal microscope with an external argon ion laser source of $488 \mathrm{~nm}$ excitation and using a band pass filter of $505-530 \mathrm{~nm}$ to detect the fluorescent DCF dye. ROS induction in response to NPs exposure was monitored by monitoring the emission of DCFH-DA dye by laser excitation. Cells were imaged using $63 \times$ oil immersion lens and ROS formation was observed in comparison to unexposed control.

\subsection{Cell cycle analysis}

The analysis was performed using BD Accuri ${ }^{\mathrm{TM}}$ C6 Flow Cytometer. Cells were seeded at a density of $1 \times 10^{6}$ cells $/ \mathrm{ml}$ in $\mathrm{T}-25 \mathrm{~cm}^{2}$ flasks each containing a total volume of $5 \mathrm{ml}$ HeLa media and incubated for $24 \mathrm{~h}$ at $37^{\circ} \mathrm{C}$ in $5 \% \mathrm{CO}_{2}$. After the $24 \mathrm{~h}$ cell attachment flasks were washed with $5 \mathrm{ml} /$ flask PBS and further treated with $5 \mathrm{ml} /$ flask of the respective 2.5-10 $\mu \mathrm{M}$ AmPs, 76.5-307 $\mu \mathrm{M} \mathrm{ZnO}$, and 57.9-231.7 $\mu \mathrm{M} \mathrm{Ag}$ NPs concentration range (Obtained from $\left(\mathrm{IC}_{50}\right)$ and (LOEC) data generated from range finding tests conducted in cytotoxicity assays) and controls prepared in HeLa media and also incubated for $24 \mathrm{~h}$. The negative control underwent a media change whereas the positive control was treated with $0.01 \mu \mathrm{g} / \mathrm{ml}$ Colcemid solution prepared in fresh media. After $24 \mathrm{~h}$ incubation, cells were harvested via enzymatic removal and centrifuged at 1200 RPM for $8 \mathrm{~min}$. After which cells were fixed in ice cold, $70 \%$ ethanol and prepared for analysis immediately or stored in the fixative at $4{ }^{\circ} \mathrm{C}$ for a maximum of two days. Briefly, for analysis, cells were washed twice with $\mathrm{PBS}$, to remove any residue fixative and re-suspended in $2 \mathrm{ml}$ PBS. About $100 \mu \mathrm{g} / \mathrm{l}$ of Ribonuclease was added to ensure only the DNA content was stained. After five minutes incubation with RNase at room temperature, the DNA content was then stained with Propidium lodide $(\mathrm{PI})$ at a staining concentration of $50 \mu \mathrm{g} / \mathrm{l}$. Three independent flasks were used for each concentration of respective AmPs, $\mathrm{ZnO}$, and Ag NPs and controls. The samples were again incubated at room temperature for $20 \mathrm{~min}$, after which it was immediately analyzed. A minimum of 10000 single cell events per sample was analyzed. Doublet exclusion was performed on the acquired data with the inbuilt area scaling function on the BD Accuri software (version 1.0.264.21).

\subsection{Caspase-3/7 activity study}

The analysis was performed using $\mathrm{BD}$ Accuri $^{\mathrm{TM}} \mathrm{C} 6$ Flow Cytometer. Cells were seeded exactly in the same manner as described earlier in the cell cycle analysis method and again $\mathrm{T}-25 \mathrm{~cm}^{2}$ flasks with three replicates of $3 \mu \mathrm{M} \mathrm{AmPs}, 368.4 \mu \mathrm{M}$ $\mathrm{ZnO}$, and $139.06 \mu \mathrm{M}$ Ag NPs concentrations and controls prepared in HeLa media were incubated for $24 \mathrm{~h}$ at $37^{\circ} \mathrm{C}$ in $5 \%$ $\mathrm{CO}_{2}$. Cells with solely HeLa media were used as a negative control and cells with HeLa media and treated with Doxorubicin hydrochloride (DOX) at $0.1 \mu \mathrm{M}$ concentration were used as a positive control which is a pro-apoptotic inducer. Following $24 \mathrm{~h}$ incubation period with $\mathrm{AmPs}, \mathrm{ZnO}$, and $\mathrm{Ag} \mathrm{NPs}$ and controls cells were washed with $5 \mathrm{ml} /$ flask PBS and harvested via enzymatic removal and centrifuged at 1200 RPM for $8 \mathrm{~min}$. The experiment was conducted in accordance with manufacture's instruction given in CellEvent $^{\mathrm{TM}}$ Caspase-3/7 Green Flow Cytometry Assay kit. Briefly, after harvesting, test cells were suspended in $1 \mathrm{ml}$ of PBS with \pm BSA (Bovine serum albumin) making and stained with $500 \mathrm{nM}$ of CellEvent Caspase-3/7 Green Detection reagent with an incubation time of $45 \mathrm{~min}$ at room temperature. After which $1 \mu \mathrm{M}$ of SYTOX AADvanced dead cell stain was added during final $5 \mathrm{~min}$ of incubation to the cell suspension after which it was immediately analyzed. A minimum of 10000 single cell events per sample was analyzed. Doublet exclusion was performed on the acquired data with the inbuilt area scaling on the BD Accuri software (version 1.0.264.21).

\subsection{Statistical analysis}

At least three independent experiments were conducted in triplicate for all experiments. Test results for each assay were expressed as the percentage of the unexposed control \pm standard deviation (SD). Control values were set at $100 \%$. Difference between the control and samples were evaluated using the statistical analysis package GraphPad Prism 7.0 (GraphPad Software, Inc., La Jolla, CA). The statistical significant difference was set at $p<0.05$. Normality of data was confirmed with Kolmogorov-Smirnov tests to validate the assumptions found in a one-way analysis of variance (ANOVA) and Dunnett's multiple comparison tests. Cytotoxicity data for $A B, N R$, and MTT assays were fitted to a sigmoidal curve and four parameters logistic model to calculate the $I C_{50}$ values and they were reported as $\pm 95 \%$ confidence interval. All quoted $I_{50}$ values were estimated using GraphPad Prism 7.0.

\section{Results}

\subsection{Particle characterization of AmPs, ZnO, and Ag NPs}

Morphology and diameters of NPs were evaluated using SEM analysis. NPs were predominately spherical in shape with an average size of $40 \mathrm{~nm}$ (AmPs NPs), $29 \mathrm{~nm} \mathrm{(ZnO} \mathrm{NPs),} \mathrm{and}$ $34 \mathrm{~nm}$ (Ag NPs) (Figure 1(a-c)) when dispersed in water. For a detailed understanding of the hydrodynamic diameter and the changes that occur due to NPs interaction with the biological material, in this case, protein components of cell culture media, DLS analysis was performed on all NPS in cell culture media as well as water.

Table 1 shows the average DLS measurements on NPs suspended in $\mathrm{dH}_{2} \mathrm{O}$ and RPMI cell culture media (10\% FBS). A concentration of $3 \mu \mathrm{M}$ (AmPs NPs), $368.4 \mu \mathrm{M}$ (ZnO NPs), and $139.06 \mu \mathrm{M}$ (Ag NPs) were chosen as these concentrations were noted to induce biological effects in vitro. The particle size of NPs suspended in $\mathrm{dH}_{2} \mathrm{O}$ was determined to be $32.90 \mathrm{~nm} \pm \mathrm{SD} 4.81 \mathrm{~nm}$ (AmPs NPs), $79.38 \pm$ SD $11.62 \mathrm{~nm}$ (ZnO NPs), and $38.11 \mathrm{~nm} \pm$ SD $5.57 \mathrm{~nm}$ (Ag NPs). A shift in hydrodynamic diameter was observed for all NPs suspended in cell culture media, this was attributed to their interactions with cell culture media and its added protein components as has 

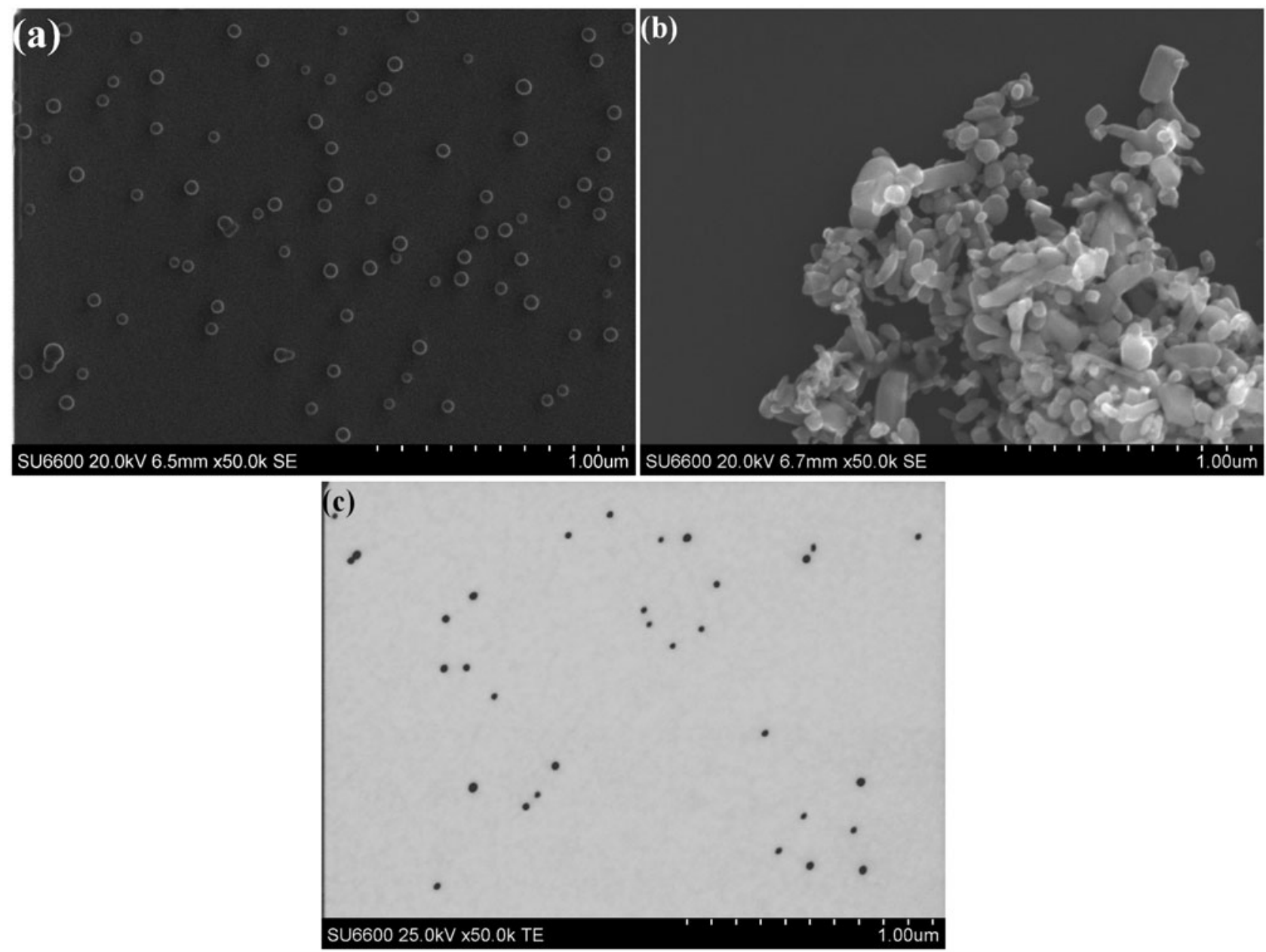

Figure 1. SEM micrograph of (a) AmPs $(1 \mu \mathrm{M})$, (b) ZnO NP $(12.28 \mu \mathrm{M})$, and (c) Ag NP $(9.27 \mu \mathrm{M})$. Scale bar of $1 \mu \mathrm{m}$ magnification $50000 \times$.

Table 1. Particle size $(\mathrm{nm})$ and Zeta Potential $(\mathrm{mV})$ for NPs (AmPs, $\mathrm{ZnO}$, and $\mathrm{Ag})$ in $\mathrm{dH}_{2} \mathrm{O}$ and HeLa media.

\begin{tabular}{lcccccrr}
\hline & HeLa media & $\begin{array}{c}1 \mu \mathrm{M} \mathrm{PS}-\mathrm{NH}_{2} \\
\text { in } \mathrm{H}_{2} \mathrm{O}\end{array}$ & $\begin{array}{c}12.28 \mu \mathrm{M} \mathrm{ZnO} \mathrm{NP} \\
\text { in } \mathrm{H}_{2} \mathrm{O}\end{array}$ & $\begin{array}{c}9.27 \mu \mathrm{M} \mathrm{Ag} \mathrm{NP} \\
\text { in } \mathrm{H}_{2} \mathrm{O}\end{array}$ & $\begin{array}{c}1 \mu \mathrm{M} \mathrm{PS}-\mathrm{NH} 2 \\
\text { in HeLa media }\end{array}$ & $\begin{array}{r}12.28 \mu \mathrm{M} \mathrm{ZnO} \mathrm{NP} \\
\text { in HeLa media }\end{array}$ & $\begin{array}{c}9.27 \mu \mathrm{M} \mathrm{Ag} \mathrm{NP} \\
\text { in HeLa media }\end{array}$ \\
\hline Diameter $(\mathrm{nm})$ & $11.69 \pm 1.21$ & $32.90 \pm 4.81$ & $79.38 \pm 11.62$ & $38.11 \pm 5.57$ & $51.11 \pm 7.48$ & $142.8 \pm 20.91$ & $59.55 \pm 4.52$ \\
Zeta Potential $(\mathrm{mV})$ & - & $30.40 \pm 2.80$ & $27.33 \pm 0.60$ & $-45.26 \pm 11.40$ & $-11 \pm 0.70$ & $-9.27 \pm 0.47$ & $-11.08 \pm 1.96$ \\
\hline
\end{tabular}

Data expressed as percentage of control mean \pm SD of three independent experiments.

been previously reported (Mukherjee et al. 2012). Two clear peaks were observed for NPs dispersed in RPMI cell culture media, one representing RPMI itself and other representing protein agglomerates of NPs in cell culture media at approximately $51 \mathrm{~nm}$ (AmPs NPs), $142 \mathrm{~nm}$ (ZnO NPs), and $59 \mathrm{~nm}$ (Ag NPs).

RPMI cell culture media was also used as a control, DLS measurements were performed on it providing average particle size distribution peak of the protein components $(10 \%$ FBS) in cell culture media to be approximately $11.69 \mathrm{~nm}$, which is typical of protein agglomerates in cell culture media.

Zeta potential analysis was performed on all NPs using the same sample preparation as for the DLS characterization and demonstrates the stability of the NPs suspension in $\mathrm{dH}_{2} \mathrm{O}$ and cell culture media (Table 1). Stability of NPs in suspension form is recognized by zeta potential values of equal to or greater than $\pm 30 \mathrm{mV}$ (Murphy et al. 2015a). Zeta potential values of Ag NPs showed the stability of particles when suspended in $\mathrm{dH}_{2} \mathrm{O}$ and moderate stability values were observed for AmPs and ZnO NPs (Table 1). All NPs upon dispersion in cell culture media yielded zeta potential values that would indicate an unstable suspension in cell culture media (Table 1). Zeta potential values for all three NPs suggests that upon dispersion in the cell culture medium with a bath sonicator the NPs form an unstable dispersion and would precipitate out with time (Mukherjee et al. 2012).

For all the NPs under test, an average particle diameter of less than $50 \mathrm{~nm}$ was recorded in both DLS measurements and SEM analysis when dispersed in $\mathrm{dH}_{2} \mathrm{O}$. However, there was an increase in the recorded diameter of all NPs with DLS analysis when measurements were performed in cell culture media instead of $\mathrm{dH}_{2} \mathrm{O}$. Differences in zeta potential for all three NPs were also observed, where zeta potential measured upon dispersion of NPs in cell culture media instead of $\mathrm{dH}_{2} \mathrm{O}$ have yielded a notable decrease in zeta potential values indicating weak stability with sedimentation likely (Table 1). 
Table 2. Calculated $\mathrm{IC}_{50}(\mu \mathrm{M})$ values resulting from AmPs, $\mathrm{ZnO}$, and $\mathrm{Ag}$ NPs exposure in HeLa cell lines from $A B, \mathrm{NR}$, and $\mathrm{MTT}$ assays.

\begin{tabular}{|c|c|c|c|c|c|c|c|c|c|}
\hline \multirow[b]{2}{*}{ NPs } & \multicolumn{3}{|c|}{$A B$ assay $I C_{50}(95 \%$ confidence interval) } & \multicolumn{3}{|c|}{ NR assay $I_{50}(95 \%$ confidence interval) } & \multicolumn{3}{|c|}{ MTT assay $\mathrm{IC}_{50}(95 \%$ confidence interval) } \\
\hline & $24 \mathrm{~h}$ & $48 \mathrm{~h}$ & $72 \mathrm{~h}$ & $24 \mathrm{~h}$ & $48 \mathrm{~h}$ & $72 \mathrm{~h}$ & $24 \mathrm{~h}$ & $48 \mathrm{~h}$ & $72 \mathrm{~h}$ \\
\hline AmPs $(\mu \mathrm{M})$ & $2.17 \pm 1.05$ & $1.33 \pm 1.05$ & $1.06 \pm 1.09$ & $6.85 \pm 1.13$ & $2.33 \pm 1.07$ & $2.32 \pm 1.17$ & $7.36 \pm 1.21$ & $2.51 \pm 1.12$ & $2.30 \pm 1.17$ \\
\hline $\mathrm{ZnO}(\mu \mathrm{M})$ & $132.01 \pm 1.08$ & $92.95 \pm 1.04$ & $117.39 \pm 1.04$ & & - & & $468.72 \pm 1.35$ & $153.5 \pm 1.11$ & $124.27 \pm 1.25$ \\
\hline $\mathrm{Ag}(\mu \mathrm{M})$ & $604.38 \pm 1.43$ & $5.74 \pm 1.49$ & $0.55 \pm 1.27$ & $134.33 \pm 1.27$ & $2.22 \pm 1.22$ & $0.013 \pm 3.48$ & $611.89 \pm 2.21$ & $19.65 \pm 1.31$ & $12.23 \pm 1.16$ \\
\hline
\end{tabular}

Data expressed as percentage of control mean \pm SD of three independent experiments.

\subsection{Toxicological evaluation of NPS}

A time- and dose-dependent response were observed for all assays (AB, NR, and MTT) and the collected cytotoxicity data of all tested NPs facilitated the calculation of $\mathrm{IC}_{50}$ values from corresponding assays (AB, NR, and MTT) presented in Table 2 . Furthermore, the ability of tested particles to induce ROS at different time points $(30-360 \mathrm{~min})$ was monitored as a function of particle concentration, with an increase in exposure time there was an increase in ROS formation observed at their respective concentrations (Figure 2(a-c)). ROS induction was further confirmed by live cell confocal microscopy, which also indicated pro-apoptotic morphological changes within HeLa cells. To further investigate the observed inhibition of cell growth involved changes in cell cycle, cell cycle phase distribution by flow cytometry was performed (Figure 4). To further quantify the live, apoptotic and necrotic in the tested HeLa cells, the cell event Caspase-3/7 flow cytometry triplex assay was performed (Figure 5).

\subsubsection{Toxicological evaluation of AmPs NPs}

Cytotoxicity evaluation of AmPs NPs. Table 2 displays the $\mathrm{IC}_{50}$ values recorded from all assays, which clearly indicates that there is a decrease in cell viability due to an increase in exposure time interval from 24 to $72 \mathrm{~h}$ for all assays. $A B$ assay was found to be the most sensitive assay for cellular viability followed by NR assay and MTT assay After $24 \mathrm{~h}$ exposure time interval, the $I C_{50}$ value observed from $A B$ assay was $2.17 \mu \mathrm{M}$ which further reduced to $1.06 \mu \mathrm{M}$ after $72 \mathrm{~h}$ exposure time interval. A similar trend was also observed for the NR and MTT assays. A significant reduction in metabolic activity, mitochondrial integrity, and lysosomal dysfunction was observed after $72 \mathrm{~h}$ exposure at a concentration of $0.625 \mu \mathrm{M}$ and above against unexposed control, while a significant reduction in cell survival at all exposure times was observed at a concentration of $1.25 \mu \mathrm{M}$ and above.

Reactive oxygen species study of AmPs NPs. A maximum amount of ROS formation was observed for $10 \mu \mathrm{M}$ AmPs NPs with a 5 -fold increase relative to the unexposed control after a $6 \mathrm{~h}$ exposure time (Figure 2(a)). For all the tested concentrations of AmPs NPs, they were found to exhibit significance difference $(p<0.05)$ against unexposed control at a concentration range of $2.5-10 \mu \mathrm{M}$ (Figure 2(a)). Similar to the cytotoxicity evaluation, the generation of intracellular hydroperoxides was noted in a time and dose-dependent manner at a concentration of $2.5 \mu \mathrm{M}$ and above. A further increase in the intracellular ROS formation was also observed with increase in exposure time interval (Figure 2(a)).

Confocal Microscopy study of AmPs NPs. Confocal fluorescent microscopy images of HeLa cells were recorded to confirm ROS induction was due to AmPs NPs exposure at a concentration of $5 \mu \mathrm{M}$ (Figure 3(a)). Increased emission of DCFH-DA dye from AmPs NPs exposed HeLa cells verified that the induction of ROS with AmPs NPs inducing a high level of ROS in comparison to unexposed HeLa cells (Figure 3(a-d)). Considerable morphological differences were also observed resulting from AmPs NPs exposure to HeLa cells, with shrinkage in cell size, nuclear condensation, blebbing, and the collapse of cell membrane indicating early proapoptotic signs (Figure 3(a)).

Flow cytometry cell cycle analysis of AmPs NPs. The cell cycle phase distribution of HeLa cells treated with $2.5-10 \mu \mathrm{M}$ AmPs NPs for $24 \mathrm{~h}$ is shown in Figure 4. AmPs NPs induced the accumulation of G2/M phase cells and decreased in the number of $G 0 / G 1$ and $S$ phase cells (Figure 4) indicating a possible arrest in the G2/M phase for tested concentrations of $5 \mu \mathrm{M}$ and above against unexposed control.

Flow cytometry cell event caspase-3/7 activity study of AmPs. When monitored, the apoptotic population of cells was found to be significantly different to that of the unexposed HeLa cells with $28.6 \%$ of the cells tested being positive for apoptosis (Figure 5). A non-significant $(p<0.05)$ trend was found in the case of necrotic cells, with just over (1\%) cell population against the unexposed HeLa cells (Figure 5). This indicated that necrosis is not a contributor to the cell death associated with the AmPs NP exposure in this study.

\subsubsection{Toxicological evaluation of $Z n O N P s$}

Cytotoxicity evaluation of $\mathrm{ZnO} N$ Ns. For $\mathrm{ZnO} N \mathrm{NP}, \mathrm{AB}$ assay was again found to be the most sensitive assay followed by MTT assay (Table 2). Whereas NR assay was found to yield inconsistent data, where unexpected high fluorescence/absorption data was recorded and the assay was deemed to be suffering from absorptive interferences as has been previously reported for other NP cytotoxicity studies using the NR assay (Casey et al. 2007). A decrease in cell viability due to an increase in exposure time interval from 24 to $72 \mathrm{~h}$ was observed for both $A B$ and MTT assays. This was similar to the findings observed from AmPs NPs exposure. After $24 \mathrm{~h}$ exposure time interval, the $\mathrm{IC}_{50}$ value calculated from $\mathrm{AB}$ assay was $132.01 \mu \mathrm{M}$ further reducing to $117.39 \mu \mathrm{M}$ after $72 \mathrm{~h}$ exposure time. A significant reduction in metabolic activity and mitochondrial integrity was observed after $72 \mathrm{~h}$ exposure at a concentration of $76.25 \mu \mathrm{M}$ and above relative to the unexposed control, while a significant reduction in cell survival at all exposure times was observed at a concentration of $38.12 \mu \mathrm{M}$ and above.

Reactive oxygen species study of ZnO NPs. A maximum amount of ROS formation was observed for $1.22 \times 10^{3} \mu \mathrm{M}$ concentration with a 1.75 -fold increase relative to the unexposed control after a $6 \mathrm{~h}$ exposure time (Figure 2(b)). For all 

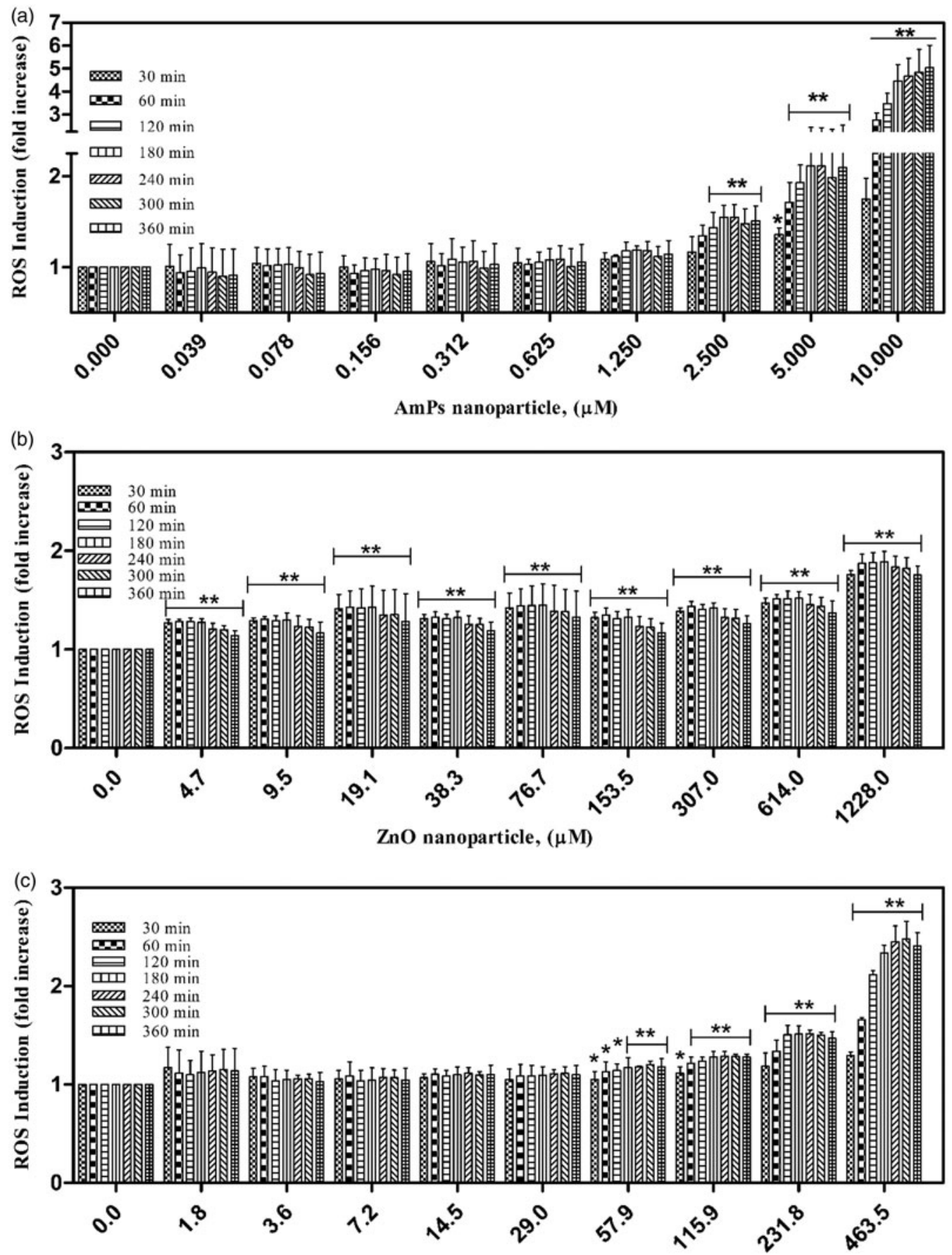

Ag nanoparticle, $(\mu \mathrm{M})$

Figure 2. ROS induction as a function of time (30-360 min) due NPs exposures in HeLa cells: (a) AmPs, (b) ZnO, and (c) Ag NPs. Data expressed as percentage of control mean \pm SD of three independent experiments. *denotes a statistically significant $(p<0.05)$ difference from the unexposed control.

the tested concentrations of $\mathrm{ZnO} \mathrm{NPs}$, at each time point, $\mathrm{ZnO}$ NPs were found to exhibit significant differences $(p<0.05)$ against the unexposed control. These findings were found to be different to the AmPs NPs ROS study, where no significant trend was observed for the lower concentration range of $0.039-1.25 \mu \mathrm{M}$ AmPs NPs exposure to HeLa cells (Figure 2(a)).

Confocal microscopy study of ZnO NPs. Increased emission of DCFH-DA dye from ZnO NPs exposed HeLa cells verified the induction of ROS with ZnO NPs at a concentration of $614 \mu \mathrm{M}$ inducing a high level of ROS against unexposed HeLa cells (Figure $3(a-d)$ ). Shrinkage in cell size and the collapse of cell membrane indicating early pro-apoptotic signs were also observed from ZnO NPs exposed HeLa cells (Figure 3(b)).

Flow cytometry cell cycle analysis of ZnO NPs. The cell cycle phase distribution of HeLa cells treated with $76.5-307 \mu \mathrm{M}$ $\mathrm{ZnO} \mathrm{NPs}$ for $24 \mathrm{~h}$ is shown in Figure 4. ZnO NPs induced the accumulation of $\mathrm{G} 2 / \mathrm{M}$ phase cells and decreased in the number of G0/G1 and S phase cells (Figure 4) indicating a possible arrest in the G2/M phase for tested concentrations of $153.5 \mu \mathrm{M}$ and above against unexposed control. These findings were similar to the findings observed from AmPs NP exposed HeLa cells. 

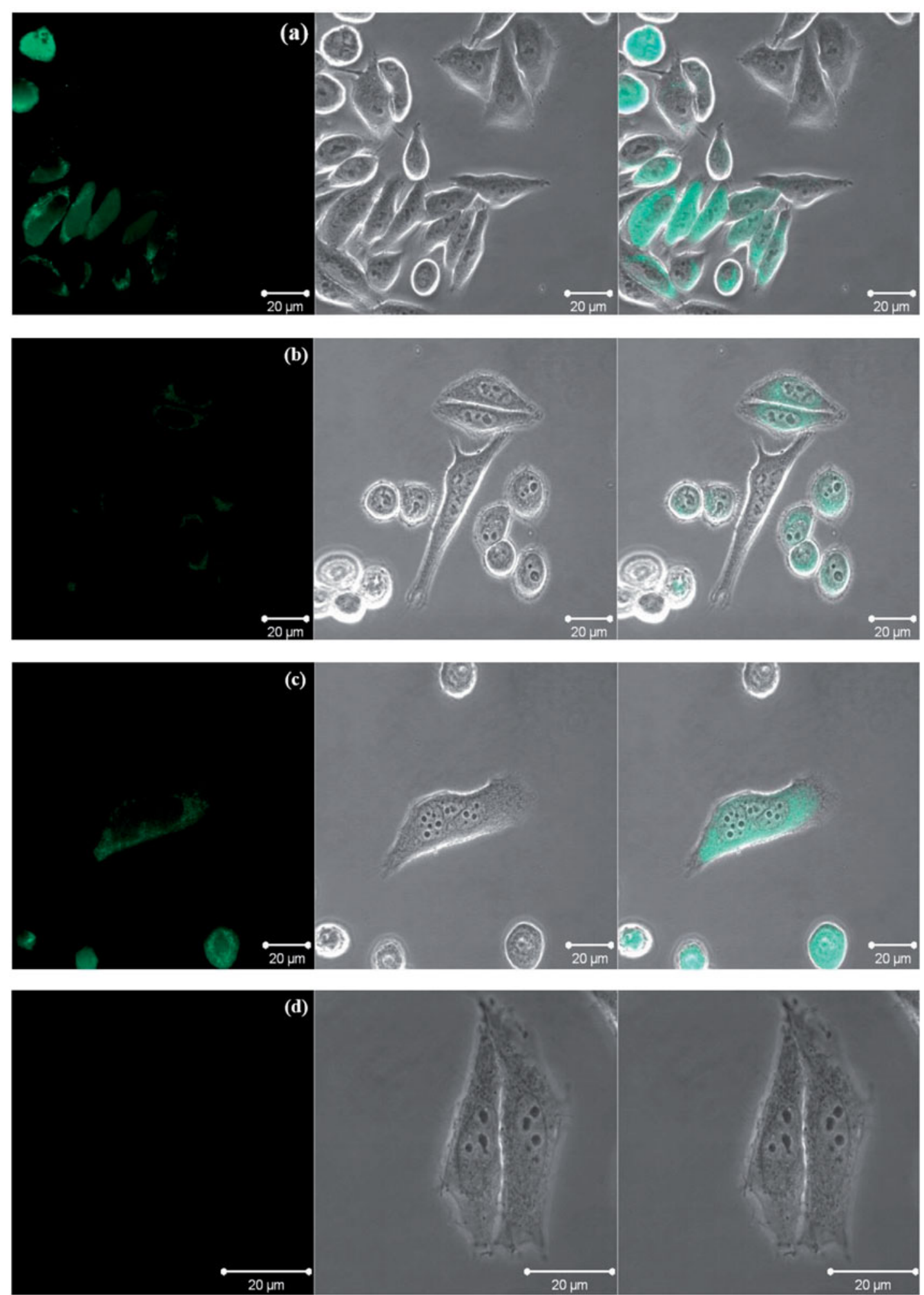

Figure 3. Confocal images of HeLa cells from NPs exposure (a) HeLa cells with $5 \mu \mathrm{M}$ AmPs exposure, (b) HeLa cells with $614 \mu \mathrm{M}$ ZnO exposure, (c) HeLa cells with $463.56 \mu \mathrm{M} \mathrm{Ag}$ exposure, and (d) HeLa cells as unexposed control.

Flow cytometry cell event caspase-3/7 study of ZnO NPs. Similar to the findings observed from AmPs NPs exposed HeLa cells, apoptotic cells were found to be significantly different to the unexposed HeLa cells and higher in number for ZnO NPs (16.13\%) (Figure 5). A non-significant $(p<0.05)$ trend was found in the case of necrotic cells, with just over (4.3\%) cell population against the unexposed HeLa cells (Figure 5).
This again indicated apoptosis as the predominant contributor to the cell death associated with the ZnO NPs exposed HeLa cells.

\subsubsection{Toxicological evaluation of ag NPs}

Cytotoxicity evaluation of $\mathrm{Ag} N \mathrm{~N}$ s. For $\mathrm{Ag} N \mathrm{NPs}, \mathrm{NR}$ assay was found be the most sensitive followed by $A B$ assay 

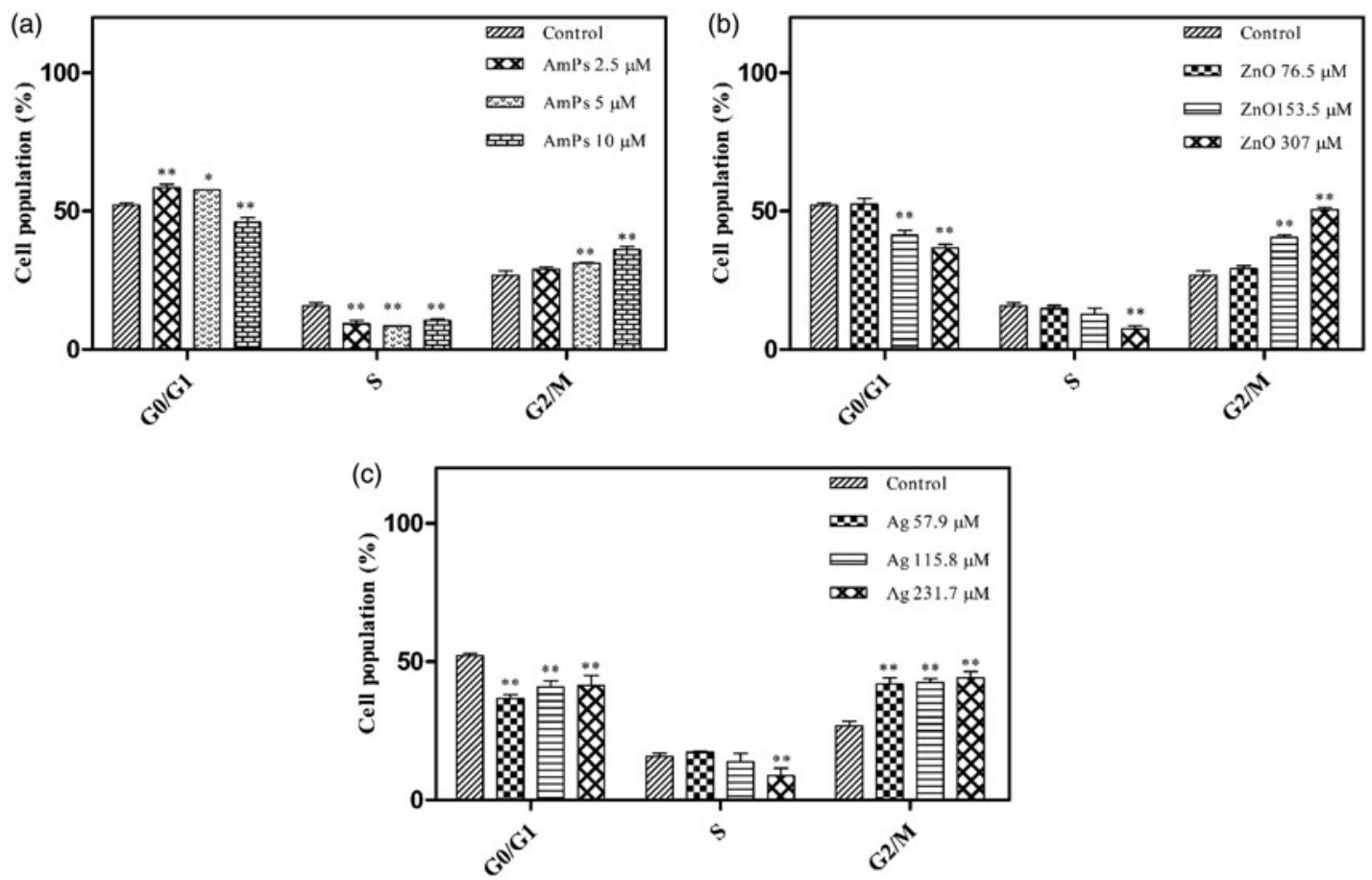

Figure 4. Cell cycle analysis of HeLa cells treated with different concentrations of NPs data is expressed as a percentage of the total population analyzed. HeLa exposure to (a) AmPs NPs, (b) ZnO NPs, and (c) Ag NPs. HeLa cells without exposure were used as negative control. Data expressed as percentage of control mean \pm SD of three independent experiments. *denotes a statistically significant $(p<0.05)$ difference from the unexposed control.

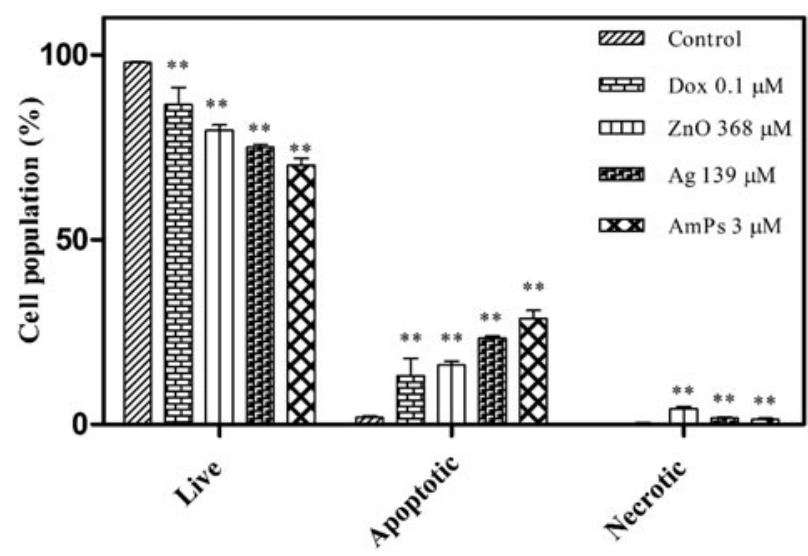

Figure 5. Flow cytometry analysis of caspase-3/7 activity as a result of NPs exposure in HeLa cells showing live, apoptotic and necrotic cell population. HeLa cells without exposure were used as negative control. Data expressed as percentage of control mean \pm SD of three independent experiments. *denotes a statistically significant $(p<0.05)$ difference from the unexposed control.

and MTT assay. Table 2 displays the $\mathrm{IC}_{50}$ values recorded from all assays, which clearly indicates that there is a decrease in cell viability due to an increase in exposure time interval from 24 to $72 \mathrm{~h}$ for Ag NPs. After $24 \mathrm{~h}$ exposure time interval, the $\mathrm{IC}_{50}$ value for the Ag NPs was $134.33 \mu \mathrm{M}$ further reducing to $0.013 \mu \mathrm{M}$ at $72 \mathrm{~h}$ exposure time. This decrease in cell viability due to an increase in exposure time was similar to the findings of AmPs NPs and ZnO NPs exposure study. Ag NPs were found to be most sensitive towards NR assay indicating lysosomal dysfunction as a major contributor to $\mathrm{Ag}$ NPs associated toxicity. A significant reduction in cell survival at all exposure times was observed at a concentration of $57.94 \mu \mathrm{M}$ and above.
Reactive oxygen species study of Ag NPs. A maximum amount of ROS formation was observed for $453.56 \mu \mathrm{M} \mathrm{Ag}$ NPs with a 2.4-fold increase relative to the unexposed control after $6 \mathrm{~h}$ exposure time (Figure 2(c)). For all the tested concentrations of Ag NPs, they were found to exhibit significance difference $(p<0.05)$ against unexposed control at 57.9-463.5 $\mu \mathrm{M}$ concentration range (Figure 2(c)).

Confocal microscopy study of Ag NPs. Increased emission of DCFH-DA dye from Ag NPs exposed HeLa cells verified the induction of ROS with $\mathrm{Ag} \mathrm{NPs}$ at a concentration of $463.54 \mu \mathrm{M}$ inducing a high level of ROS against unexposed HeLa cells (Figure 3(a-d)). Shrinkage in cell size and the collapse of cell membrane indicating early pro-apoptotic signs were also observed from Ag NPs exposed HeLa cells (Figure 3(b)). These were similar to the findings observed from AmPs and ZnO NPs exposed HeLa cells.

Flow cytometry cell cycle analysis of Ag NPs. Ag NPs were also found to induce an increase in the population of the cells in the G2/M phase cells and a decrease in the number of G0/G1 and S phase cells for all the tested concentration range. This was similar to the findings observed for AmPs NPs and ZnO NPs exposure (Figure $4(a, b)$ ) indicating a possible arrest in the G2/M phase as a result of the exposure.

Flow cytometry cell event caspase-3/7 study of Ag NPs. Apoptotic cells were found to be significantly different to the unexposed HeLa cells and higher in number (23.36\%), which were similar to the finding of AmPs NPs and $\mathrm{ZnO} N P s$ exposed cells (Figure 5). A non-significant $(p<0.05)$ trend was found in the case of necrotic cells, where only (1\%) are found for Ag NPs exposed cells (Figure 5). This indicated that necrosis is not a contributor to the cell death associated with the Ag NPs exposures in this study similar to the 
findings observed earlier for AmPs NPs and $\mathrm{ZnO}$ NPs exposed cells.

\section{Discussion}

This study examines the effect of AmPs, ZnO, and Ag NPs on HeLa cells as a model test cells. The aim of this study was to evaluate potential toxicity and associated mechanism involved in the toxicity of AmPs, $\mathrm{ZnO}$, and Ag NPs which are different in their physiochemical properties by comparing their effects on a model cell line (HeLa cells). The physiochemical characteristics of NPs are known to play an important role in their interaction with biological systems, where size, surface area, shape, and chemical composition are factors which are of great influence to a NPs toxicity (Warheit 2008, Sur et al. 2012).

The DLS measurements performed in this study verified that all the test materials had an average diameter below $<50 \mathrm{~nm}$ and this was subsequently confirmed by SEM analysis. An increase in the recorded diameter of all NPs was noted when the NPs were dispersed in HeLa media instead of $\mathrm{dH}_{2} \mathrm{O}$ (Table 1). This indicates possible interactions of NPs with cell culture added protein components (10\% FBS). This was similar to the findings previously reported in other studies involving NPs, which ultimately leads to the formation of 'Protein corona' (Lundqvist et al. 2008, Lynch and Dawson 2008) and the increase in the particle size was deemed to be due to a protein coating due to the added FBS in the cell culture medium. Zeta potential analysis of the NPs has shown to play a significant role in its interactions with biomolecules (Vila et al. 2002) and its change in the exposure medium has been shown to correlate well with toxic response (Naha et al. 2009, Mukherjee et al. 2010). Differences in zeta potential for all three NPs were observed in this study. When the zeta potential was measured upon dispersion of NPs in cell culture media instead of $\mathrm{dH}_{2} \mathrm{O}$, there was a marked decrease in the magnitude of zeta potential observed in the case of AmPs, ZnO NP, and Ag NPs (Table 1). This indicated a reduced stability of the NPs with a tendency to sediment in the cell culture medium. Changes in the zeta potential of this nature confirm that there was an interaction of NPs with cell culture media components (10\% FBS), as previously reported (Casey et al. 2007, 2008). It has also been postulated that such medium interactions were independent of cell culture medium serum content and that interaction may reduce the availability of essential medium components to cultured cells further resulting in an indirect cytotoxicity due to medium depletion by interactions (Casey et al. 2008). However, this was isolated to carbonaceous NP and was not observed in a separate test with similar test particles (Mukherjee et al. 2012) and as such deemed not to be a significant contributor to the particles tested in this study.

Once the physiochemical properties had been fully characterized and the size ranges verified of the test materials, biological testing began. Table 2 displays the cytotoxicity data, in the form of $I_{50}$ values, obtained for the $A B, N R$, and $M T T$ viability assays for all three NPs. These assays showed a doseand time-dependent decrease in cell viability from 24 to $72 \mathrm{~h}$. This effect was mirrored in the calculated $I C_{50}$ values for all three NPs, indicative of a complex cascade of events triggered by different mechanisms, giving rise to subsequent oxidative stress, and apoptosis induced cell death (Maher et al. 2014, Efeoglu et al. 2016).

The $A B$ assay indicated that AmPs NPs exhibit a higher degree of cytotoxicity in comparison to that of the $\mathrm{ZnO}$ and Ag NPs with large differences observed at low concentrations in the 24 and $48 \mathrm{~h}$ exposure times. In the case of the Ag NPs cytotoxicity was notably time-dependent with the observed effects increasing dramatically from 24 to $72 \mathrm{~h}$ which resulted in a further decrease in $I C_{50}$ values. The $A B$ assay measures the toxic effect on basic cellular metabolism and proliferation of the cells, quantified by a decrease in the reduction of $A B$ dye from Resazurin to Resorufin between viable cell populations. The exact mechanism by which the reduction reaction of $A B$ occurs is unknown and has multiple cellular conversion sites within the cell, but the overall activity or health of the cell population can be observed by $A B$ assay (White et al. 1996, O'Brien et al. 2000).

A similar trend was also observed with the NR assay, where a decrease in cell viability with an increase in dose and exposure time of the NPs has been observed from the calculated $I C_{50}$ values reflecting this trend (Table 2). As with the $A B$ assay, a marked increase in the Ag NPs associated cytotoxicity was observed as the exposure time increased from 24 to $72 \mathrm{~h}$ with the NR assay. With the exception of the $\mathrm{ZnO} N P s$, the NR assay exhibited a similar trend to that of the $A B$ assay, with cytotoxicity increasing with both dose and exposure time. The NR assay is based on the uptake and retention of the NR dye by lysosomes in viable cells. In dead cells, NR can no longer be retained in the cytoplasmic vacuoles as the plasma membrane does not act as a barrier to retain the NR within the cells (Mukherjee et al. 2012). But the observed results for $\mathrm{ZnO} N \mathrm{Ns}$ in the case of NR assay were found to be inconsistent resulting in unexpected fluorescence/absorption data recorded, which can be due to $\mathrm{ZnO}$ NPs adsorptive interference with NR dye. Similar false or inconsistent readings due to absorptive interference between nano carbon black and the NR dye have been reported previously, where even in the absence of human epidermal keratinocytes, a false negative signal was generated and inaccurately indicating cellular viability (Casey et al. 2007).

The last assay employed was that of the MTT, the assay measures the cellular viability based on a formazan product formation which relates explicitly to the mitochondrial activity of the cells (Mosmann 1983). Again, a time-dependent reduction in cell viability was also observed for all three NPs with this assay. When compared to the unexposed HeLa cells, the toxic dose of AmPs NPs was found to be significant $(p<0.05)$ at $10-0.625 \mu \mathrm{M}$ concentration range, whereas $\mathrm{Ag} \mathrm{NPs}$ and $\mathrm{ZnO}$ NPs associated toxicity were observed at all concentrations ( $p<0.05$ ) (Table 2).

In summary, AmPs and ZnO NPs indicated, with the $A B$ assay, a change in their cellular metabolism as a major factor contributing to their cytotoxicity. This is likely due to the surface amine groups in the case of AmPs NPs (Paget et al. 2015) and the formation of $\mathrm{Zn}^{2+}$ ions in cell culture medium due to ZnO NPs dissolution (Saptarshi et al. 2015). Whereas a marked increase in Ag NPs associated cytotoxicity was 
observed with the NR assay. This would indicate a high level of lysosomal dysfunction possibly due to lysosomal alkalization by a high level of dissociated $\mathrm{Ag}^{+}$ions from Ag NPs due to their accumulation in the acidic lysosomal environment with increased exposure time intervals (Miyayama and Matsuoka 2016) (Table 2).

As with the cytotoxicity studies, a consistent dose and time-dependent increase in the generation of ROS after NPs exposure to HeLa cells was observed (Figure 2). ROS generation in the HeLa cells were noted to be statistically $(p<0.05)$ significant when compared to the unexposed controls for all the tested concentrations in a time and dose-dependent manner for $\mathrm{ZnO} N \mathrm{NP}$ and over a dose range of $(2.5-10 \mu \mathrm{M})$ for AmPs NPs and (57.9-463.5 $\mu \mathrm{M})$ Ag NPs. Of all the tested NPs AmPs NPs were noted to induce the highest level of ROS followed by Ag NPs and then ZnO NPs (Figure 2).

In the case of AmPs NPs, it has previously been reported that ROS is first generated around cell membrane and in the cytosol region of lysosomes, where they are trafficked from endosomes to lysosomes, which subsequently impacts on the mitochondria (Lunov et al. 2011, Efeoglu et al. 2016) and the previously observed MTT cytotoxicity data would support this (Table 2). For $\mathrm{ZnO} N \mathrm{NP}$, the increase in ROS formation can attribute to the extracellular dissolution of $\mathrm{ZnO} N P s$ due to the acidic microenvironment of cancer cells as was observed previously from the $A B$ cytotoxicity data (Figure 2(b)). Similarly, for Ag NPs, ROS generation can contribute to the impairment of the mitochondria function of the cell, which results in a change in redox potential equilibrium as observed previously from the MTT cytotoxicity data (Figure 2(c)).

Finally, ROS formation as a result of $\mathrm{Ag}$ and $\mathrm{ZnO} \mathrm{NPs}$ exposure can cause a change in cell function and cellular lipid peroxidation resulting in the enhancement of ROS production while simultaneously quenching naturally occurring antioxidants (Premanathan et al. 2011, Adeyemi and Faniyan 2014, Zhao et al. 2016, Zhu et al. 2016). This triggers an inflammatory response and induces DNA damage within the cell and ultimately resulting in cell death ( $\mathrm{Nel}$ et al. 2006, $\mathrm{Yu}$ et al. 2013, Murphy et al. 2015b, Saini et al. 2016).

The mechanism of cell death caused by NPs has been attributed to oxidative stress, with ROS generation indicated as a primary mechanism of NP related apoptotic cell death (Sastre et al. 2000, Piao et al. 2011, Yu et al. 2013, Murphy et al. 2015a, Saini et al. 2016, Zhao et al. 2016, Zhu et al. 2016). ROS generation in the cells is regulated by protective enzymes and antioxidant mechanisms. ROS is generated under normal physiological conditions and continuously eliminated by normally occurring antioxidants. It has also been reported that the ROS formation and the cell protection mechanism works through the cross-talk between cytosolic events and mitochondrial events upon the presence of ROS (Efeoglu et al. 2016). ROS generation is an important factor in triggering cellular pathways which can lead to cell death, such as cytokine activation (Brown et al. 2004), caspase activation (Stennicke et al. 1998, Kim et al. 2009) and damage to nuclear DNA by the alteration of the chemical structure of nucleotide bases and deoxyribosyl backbone (Cooke et al. 2003, Valko et al. 2004). It has also been previously reported that the mitochondria play a significant role in the regulation of cellular redox equilibrium which in turn maintains the viability of cells and acts as the main source of cellular ROS metabolism (Kowaltowski et al. 2009). As such excessive production of ROS can also be attributed to the reduction of MMP which causes an increase the ROS formation (Chairuangkitti et al. 2013) and induce mitochondrial pathway-dependent cell death (Hussain et al. 2005, Hsin et al. 2008).

The mechanism of cell death as a result of ROS production from induced NPs associated cytotoxicity was further evaluated by cell cycle analysis and live, apoptotic and necrotic (cell event caspase-3/7 assay) was performed using flow cytometry analysis. Exposure from all three NPs significantly $(p<0.05)$ increased the accumulation of $\mathrm{G} 2 / \mathrm{M}$ phase cells, with a concurrent decrease in the cells at G0/G1 and $S$ phase indicating cell cycle arrest at G2/M phase. This result is in agreement with previous findings, where an increase in the number of cells in G2/M phase is related to apoptosis (Fang and Beland 2009, Zhang et al. 2009, Lee et al. 2011). In the present study, AmPs, $\mathrm{ZnO}$ and Ag NPs significantly induced G2/M Phase arrest within $24 \mathrm{~h}$, resulting in a decrease in the number of cells in G0/G1 and S phase (Figure 4). Significant caspase-3/7 activation was observed indicating an increase in the population of apoptotic cells for all tested NPs exposed HeLa cells, further indicating G2/M phase arrest related apoptosis (Lee et al. 2011, Govender et al. 2013). The mechanism of apoptosis involves a cascade of initiator and executioner caspases from signal transduction (Shi et al. 2000), where executioner caspases-3/7 cleave specific substrates and then result in morphological changes in the cells linked with apoptosis and ultimately cell death (Kasibhatla and Tseng 2003, Govender et al. 2013). NPs exposure to HeLa cells was found to be statistically $(p<0.05)$ significant for all three NPs in comparison to unexposed cells with the following trend AmPs $>\mathrm{Ag}>\mathrm{ZnO}$ NPs which is in agreement with the cytotoxicity data recorded in this study (Figure 5). Interestingly no significant differences between the NPs exposed cells and that of the null control cells were observed in the population of necrotic cells, which indicates apoptosis as the primary route of cell death.

The data presented in this study verified that AmPs NPs induced cytotoxicity is initiated by the formation of ROS and caspase mediation triggering apoptotic pathway. Further studies can now also be conducted to fully understand the mechanism associated with B cell lymphoma 2 (BCl-2) proteins located on the mitochondrial membrane which cause the formation of holes which further release apoptogenic factors and trigger caspase activity as postulated earlier (Xia et al. 2008, Bexiga et al. 2011, Ruenraroengsak et al. 2012, Anguissola et al. 2014). Similarly, it also verified that $\mathrm{ZnO}$ NPs induced cytotoxicity was attributed to an increase in ROS formation, resulting in the collapse of the mitochondrial membrane and ultimately result in caspase-mediated cell cycle arrest due to the extracellular dissolution of $\mathrm{ZnO} \mathrm{NPs}$ in acidic micro-environment in HeLa cells. It also verifies that the Ag NPs induced cytotoxicity due to cell cycle disruption by a G2/M phase cell arrest and caspase 3/7 activation with resultant DNA damage in HeLa cells. 
The observed cytotoxic effect of all the three NPs tested on HeLa cells provided an insight into their mechanism of action, but all the tested NPs regardless of their surface groups and physiochemical properties resulted in ROS stress with a G2/M phase cell arrest and ultimately resulted in a caspase-mediated apoptosis.

\section{Conclusion}

The cellular response was quantified for all the tested NPs by $A B, N R, M T T$, and ROS measurements. It was observed that all three NPs resulted in a time and dose-dependent cytotoxicity. This was confirmed by an increase in intracellular ROS production, cell cycle arrest, at G2/M phase, and caspase-mediated apoptosis by the activation of caspase-3/7. The tested NPs were found to induce cytotoxicity in a trend of AmPs $>$ AgNPs $>$ ZnO NPs, which is irrespective of their differences in physiochemical properties and attached surface groups. This study has clearly demonstrated the cytotoxicity of nanoparticles (AmPs, $\mathrm{ZnO}$, and Ag NPs) with different physiochemical properties, but of similar size distribution had little effect on the generation/alteration of a cellular response of HeLa cells.

\section{Disclosure statement}

The authors declare there are no conflicts of interest.

\section{Funding}

Alan Casey acknowledges the support of Science Foundation Ireland Principle Investigator Award 11/PI/1108.

\section{References}

Adeyemi, O.S. and Faniyan, T.O., 2014. Antioxidant status of rats administered silver nanoparticles orally. Journal of Taibah University Medical Sciences, 9 (3), 182-186.

Anguissola, S., et al., 2014. High content analysis provides mechanistic insights on the pathways of toxicity induced by amine-modified polystyrene nanoparticles. PLoS One, 9 (9), e108025.

Auffan, M., et al., 2009. Towards a definition of inorganic nanoparticles from an environmental, health and safety perspective. Nature Nanotechnology, 4 (10), 634-641.

Bexiga, M.G., et al., 2011. Cationic nanoparticles induce caspase 3-, 7- and 9-mediated cytotoxicity in a human astrocytoma cell line. Nanotoxicology, 5 (4), 557-567.

Brown, D.M., et al., 2004. Calcium and ROS-mediated activation of transcription factors and TNF-cytokine gene expression in macrophages exposed to ultrafine particles. American Journal of Physiology: Lung Cellular and Molecular Physiology, 286 (2), L344-L353.

Casey, A., et al., 2007. Spectroscopic analysis confirms the interactions between single walled carbon nanotubes and various dyes commonly used to assess cytotoxicity. Carbon, 45 (7), 1425-1432.

Casey, A., et al., 2008. Single walled carbon nanotubes induce indirect cytotoxicity by medium depletion in A549 lung cells. Toxicology Letters, 179 (2), 78-84.

Chairuangkitti, P., et al., 2013. Silver nanoparticles induce toxicity in A549 cells via ROS-dependent and ROS-independent pathways. Toxicology In Vitro, 27 (1), 330-338.
Chen, H.-W., et al., 2006. Titanium dioxide nanoparticles induce emphy sema-like lung injury in mice. The FASEB Journal, 20 (13), 2393-2395.

Cho, W.-S., et al., 2011. Progressive severe lung injury by zinc oxide nanoparticles; the role of $\mathrm{Zn}^{2+}$ dissolution inside lysosomes. Particle and Fibre Toxicology, 8 (1), 27.

Cohen, M.S., et al., 2007. In vitro analysis of a nanocrystalline silver-coated surgical mesh. Surgical Infections, 8 (3), 397-404.

Cooke, M.S., et al., 2003. Oxidative DNA damage: mechanisms, mutation, and disease. FASEB Journal, 17 (10), 1195-1214.

De Matteis, V., 2017. Exposure to inorganic nanoparticles: routes of entry, immune response, biodistribution and in vitro/in vivo toxicity evaluation. Toxics, 5 (4), E29.

Dingchao, C., Jie, Y., and Yanli, Z., 2004. Antibacterial materials of silver nanoparticles application in medical appliances and appliances for daily use. Chinese Medical Equipment Journal, 25 (11), 27-30.

Efeoglu, E., Casey, A., and Byrne, H., 2016. In vitro monitoring of time and dose dependent cytotoxicity of aminated nanoparticles using Raman spectroscopy. The Analyst, 141, 5417-5431.

Everett, W.N., et al., 2014. Phosphate-enhanced cytotoxicity of zinc oxide nanoparticles and agglomerates. Toxicology Letters, 225 (1), 177-184.

Fang, J.L. and Beland, F.A., 2009. Long-term exposure to zidovudine delays cell cycle progression, induces apoptosis, and decreases telomerase activity in human hepatocytes. Toxicological Sciences, 111 (1) 120-130.

Govender, R., et al., 2013. Silver nanoparticles of Albizia adianthifolia: the induction of apoptosis in human lung carcinoma cell line. Journal of Nanobiotechnology, 11 (1), 5.

Haynes, C.L., 2010. The emerging field of nanotoxicology. Analytical and Bioanalytical Chemistry, 398 (2), 587-588.

Hsiao, I.L. and Huang, Y.J., 2013. Effects of serum on cytotoxicity of nano- and micro-sized ZnO particles. Journal of Nanoparticle Research: An Interdisciplinary Forum for Nanoscale Science and Technology, 15 1829.

Hsin, Y.H., et al., 2008. The apoptotic effect of nanosilver is mediated by a ROS- and JNK-dependent mechanism involving the mitochondrial pathway in NIH3T3 cells. Toxicology Letters, 179 (3), 130-139.

Hussain, S.M., et al., 2005. In vitro toxicity of nanoparticles in BRL 3A rat liver cells. Toxicology In Vitro: An International Journal Published in Association with Bibra, 19 (7), 975-983.

Jeong, S.H., et al., 2013. ZnO nanoparticles induce TNF- $\alpha$ expression via ROS-ERK-Egr-1 pathway in human keratinocytes. Journal of Dermatological Science, 72 (3), 263-273.

Kao, Y.Y., et al., 2012. Zinc oxide nanoparticles interfere with zinc ion homeostasis to cause cytotoxicity. Toxicological Sciences, 125 (2), 462-472.

Kasibhatla, S. and Tseng, B., 2003. Why target apoptosis in cancer treatment? Molecular Cancer Therapeutics, 2 (6), 573-580.

Khan, M., Naqvi, A.H., and Ahmad, M., 2015. Comparative study of the cytotoxic and genotoxic potentials of zinc oxide and titanium dioxide nanoparticles. Toxicology Reports, 2, 765-774.

Kim, S., et al., 2009. Oxidative stress-dependent toxicity of silver nanoparticles in human hepatoma cells. Toxicology In Vitro: An International Journal Published in Association with Bibra, 23 (6), 1076-1084.

Kovács, D., et al., 2016. Silver nanoparticles defeat p53-positive and p53negative osteosarcoma cells by triggering mitochondrial stress and apoptosis. Scientific Reports, 6, 27902.

Kowaltowski, A.J., et al., 2009. Mitochondria and reactive oxygen species. Free Radical Biology \& Medicine, 47 (4), 333-343.

Lansdown, A.B.G., 2006. Silver in health care: antimicrobial effects and safety in use. Current Problems in Dermatology, 33, 17-34.

Lee, Y.S., et al., 2011. Silver nanoparticles induce apoptosis and G2/M arrest via PKC??-dependent signaling in A549 lung cells. Archives of Toxicology, 85 (12), 1529-1540.

Lundqvist, M., et al., 2008. Nanoparticle size and surface properties determine the protein corona with possible implications for biological impacts. Proceedings of the National Academy of Sciences of the United States of America, 105 (38), 14265-14270.

Lunov, O., et al., 2011. Amino-functionalized polystyrene nanoparticles activate the NLRP3 inflammasome in human macrophages. ACS Nano, 5 (12), 9648-9657. 
Lynch, I. and Dawson, K.A., 2008. Protein-nanoparticle interactions. Nano Today, 3 (1), 40-47.

Maher, M.A., et al., 2014. Numerical simulations of in vitro nanoparticle toxicity - the case of poly(amido amine) dendrimers. Toxicology In Vitro, 28 (8), 1449-1460.

McShan, D., Ray, P.C., and Yu, H., 2014. Molecular toxicity mechanism of nanosilver. Journal of Food and Drug Analysis, 22 (1), 116-127.

Miyayama, T. and Matsuoka, M., 2016. Involvement of lysosomal dysfunction in silver nanoparticle-induced cellular damage in A549 human lung alveolar epithelial cells. Journal of Occupational Medicine and Toxicology (Toxicology), 11, 1.

Mosmann, T., 1983. Rapid colorimetric assay for cellular growth and survival: application to proliferation and cytotoxicity assays. Journal of Immunological Methods, 65 (1-2), 55-63.

$\mathrm{Mu}, \mathrm{Q}$., et al., 2012. Mechanism of cellular uptake of genotoxic silica nanoparticles. Particle and Fibre Toxicology, 9 (1), 29.

Muangman, P., et al., 2006. Comparison of efficacy of $1 \%$ silver sulfadiazine and Acticoat for treatment of partial-thickness burn wounds. Journal of the Medical Association of Thailand, Chotmaihet Thangphaet, 89 (7), 953-958.

Mukherjee, S.G., et al., 2012. Comparative in vitro cytotoxicity study of silver nanoparticle on two mammalian cell lines. Toxicology In Vitro, 26 (2), 238-251.

Mukherjee, S.P., Davoren, M., and Byrne, H.J., 2010. In vitro mammalian cytotoxicological study of PAMAM dendrimers - towards quantitative structure activity relationships. Toxicology In Vitro, 24 (1), 169-177.

Murphy, A., et al., 2015a. Potential of biofluid components to modify silver nanoparticle toxicity. Journal of Applied Toxicology, 35 (6), 665-680.

Murphy, A., et al., 2015b. The surfactant dipalmitoylphophatidylcholine modifies acute responses in alveolar carcinoma cells in response to low-dose silver nanoparticle exposure. Journal of Applied Toxicology, 35 (10), 1141-1149.

Murphy, A., et al., 2016. Silver nanoparticles induce pro-inflammatory gene expression and inflammasome activation in human monocytes. Journal of Applied Toxicology, 36 (10), 1311-1320.

Naha, P.C., et al., 2009. Preparation, characterization of NIPAM and NIPAM/BAM copolymer nanoparticles and their acute toxicity testing using an aquatic test battery. Aquatic Toxicology, 92 (3), 146-154.

Nel, A., et al., 2006. Toxic potential of materials at the nanolevel. Science (New York, N.Y.), 311 (5761), 622-627.

O'Brien, J., et al., 2000. Investigation of the Alamar Blue (resazurin) fluorescent dye for the assessment of mammalian cell cytotoxicity. European Journal of Biochemistry, 267 (17), 5421-5426.

Paget, V., et al., 2015. Specific uptake and genotoxicity induced by polystyrene nanobeads with distinct surface chemistry on human lung epithelial cells and macrophages. PLoS One, 10 (4), e0123297.

Piao, M.J., et al., 2011. Silver nanoparticles induce oxidative cell damage in human liver cells through inhibition of reduced glutathione and induction of mitochondria-involved apoptosis. Toxicology Letters, 201 (1), 92-100.

Pokhrel, S., et al., 2009. Comparison of the mechanism of toxicity of binary and mixed binary metal oxide nanoparticles based on dissolution and oxidative stress properties. Chemie Ingenieur Technik, 81 (8), 1167-1167.

Premanathan, M., et al., 2011. Selective toxicity of ZnO nanoparticles toward Gram-positive bacteria and cancer cells by apoptosis through lipid peroxidation. Nanomedicine: Nanotechnology, Biology and Medicine, 7 (2), 184-192.,

Roiter, Y., et al., 2008. Interaction of nanoparticles with lipid membrane. Nano Letters, 8 (3), 941-944.

Ruenraroengsak, P., et al., 2012. Respiratory epithelial cytotoxicity and membrane damage (holes) caused by amine-modified nanoparticles. Nanotoxicology, 6 (1), 94-108.

Saini, P., et al., 2016. Evidence of reactive oxygen species (ROS) mediated apoptosis in Setaria cervi induced by green silver nanoparticles from Acacia auriculiformis at a very low dose. Experimental Parasitology, 160, 39-48.

Saptarshi, S.R., Duschl, A., and Lopata, A.L., 2013. Interaction of nanoparticles with proteins: relation to bio-reactivity of the nanoparticle. Journal of Nanobiotechnology, 11 (1), 26.
Saptarshi, S.R., Duschl, A., and Lopata, A.L., 2015. Biological reactivity of zinc oxide nanoparticles with mammalian test systems: an overview. Nanomedicine, 10 (13), 2075-2092.

Sastre, F.V., et al., 2000. Mitochondrial oxidative stress plays a key role in aging and apoptosis. IUBMB Life (International Union of Biochemistry and Molecular Biology: Life), 49 (5), 427-435.

Senapati, V.A., et al., 2017. Zinc oxide nanoparticle induced age dependent immunotoxicity in BALB/C mice. Toxicology Research, 6 (3), 342-352.

Shalini, D., Senthilkumar, S., and Rajaguru, P., 2017. Effect of size and shape on toxicity of zinc oxide ( $\mathrm{ZnO}$ ) nanomaterials in human peripheral blood lymphocytes. Toxicology Mechanisms and Methods, 28 (2), 87-94.

Shang, L., et al., 2014. Nanoparticles interacting with proteins and cells: a systematic study of protein surface charge effects. Advanced Materials Interfaces, 1 (2), 1300079.

Shapero, K., et al., 2011. Time and space resolved uptake study of silica nanoparticles by human cells. Molecular BioSystems, 7 (2), 371-378.

Shi, Y., et al., 2000. Structural and biochemical basis of apoptotic activation by Smac/DIABLO. Nature, 406 (6798), 855-862.

Singh, R.P. and Ramarao, P., 2012. Cellular uptake, intracellular trafficking and cytotoxicity of silver nanoparticles. Toxicology Letters, 213 (2), 249-259.

Sotiriou, G.A. and Pratsinis, S.E., 2010. Antibacterial activity of nanosilver ions and particles. Environmental Science \& Technology, 44 (14), 5649-5654.

Stennicke, H.R., et al., 1998. Pro-caspase-3 is a major physiologic target of caspase-8. Journal of Biological Chemistry, 273 (42), 27084-27090.

Sur, l., et al., 2012. The influence of the surface chemistry of silver nanoparticles on cell death. Nanotechnology, 23 (37), 375102

Treuel, L., Jiang, X., and Nienhaus, G.U., 2013. New views on cellular uptake and trafficking of manufactured nanoparticles. Journal of the Royal Society Interface, 10 (82), 20120939-20120939.

Valko, M., et al., 2004. Role of oxygen radicals in DNA damage and cancer incidence. Molecular and Cellular Biochemistry, 266 (1-2), 37-56.

Vamanu, C.I, et al., 2008. Induction of cell death by $\mathrm{TiO}_{2}$ nanoparticles: Studies on a human monoblastoid cell line. Toxicology In Vitro, 22 (7), 1689-1696.

Vila, A., et al., 2002. Design of biodegradable particles for protein delivery. Journal of Controlled Release, 78 (1-3), 15-24.

Vishwakarma, V., Samal, S.S., and Manoharan, N., 2010. Safety and risk associated with nanoparticles - a review. Journal of Minerals and Materials Characterization and Engineering, 9 (5), 455-459.

Wang, F., et al., 2013. The biomolecular corona is retained during nanoparticle uptake and protects the cells from the damage induced by cationic nanoparticles until degraded in the lysosomes. Nanomedicine: Nanotechnology, Biology and Medicine, 9 (8), 1159-1168.

Warheit, D.B., 2008. How meaningful are the results of nanotoxicity studies in the absence of adequate material characterization? Toxicological Sciences, 101 (2), 183-185.

White, M.J., DiCaprio, M.J., and Greenberg, D.A., 1996. Assessment of neuronal viability with Alamar blue in cortical and granule cell cultures. Journal of Neuroscience Methods, 70 (2), 195-200.

Wilhelmi, V., et al., 2012. Evaluation of apoptosis induced by nanoparticles and fine particles in RAW 264.7 macrophages: facts and artefacts. Toxicology In Vitro: An International Journal Published in Association with Bibra, 26 (2), 323-334.

Xia, T., et al., 2008. Cationic polystyrene nanosphere toxicity depends on cell-specific endocytic and mitochondrial injury pathways. ACS Nano, 2 (1), 85-96.

Yan, Z., et al., 2014. Transcriptional and posttranscriptional regulation and endocytosis were involved in zinc oxide nanoparticle-induced interleukin-8 overexpression in human bronchial epithelial cells. Cell Biology and Toxicology, 30 (2), 79-88.

Yang, Q. and Ma, Y., 2014. Irradiation-enhanced cytotoxicity of zinc oxide nanoparticles. International Journal of Toxicology, 33 (3), 187-203.

Yu, K.-N., et al., 2013. Zinc oxide nanoparticle induced autophagic cell death and mitochondrial damage via reactive oxygen species generation. Toxicology In Vitro, 27 (4), 1187-1195. 
Zhang, J., et al., 2017. Zinc oxide nanoparticles harness autophagy to induce cell death in lung epithelial cells. Cell Death and Disease, 8 (7), e2954.

Zhang, L., et al., 2009. Efficient activation of p53 pathway in A549 cells exposed to L2, a novel compound targeting p53-MDM2 interaction. Anti-Cancer Drugs, 20 (6), 416-424.

Zhang, T., et al., 2014. Cytotoxic potential of silver nanoparticles. Yonsei Medical Journal, 55 (2), 283-291.
Zhao, X., et al., 2016. Zinc oxide nanoparticles induce oxidative DNA damage and ROS-triggered mitochondria-mediated apoptosis in zebrafish embryos. Aquatic Toxicology, 180, 56-70.

Zhu, B., et al., 2016. Silver nanoparticles induce HePG-2 cells apoptosis through ROS-mediated signaling pathways. Nanoscale Research Letters, 11 (1), 198. 